\title{
ABNORMAL RENAL TUBULAR BACK-DIFFUSION FOLLOWING ANURIA
}

\author{
By JULES REDISH, JOSEPH R. WEST, BETTY W. WHITEHEAD, AND \\ HERBERT CHASIS \\ (From the Departments of Medicine and Pediatrics, New York University College of Medicine; \\ and the Third (New York University) Medical and Pediatric Services, \\ Bellevue Hospital)
}

(Received for publication April 21, 1947)

A negative value for $T_{m p-a m i n o b i p p u r a t e}$ was observed in a patient with sulfathiazole intoxication following 4 days of anuria and 5 days of marked oliguria. This negative $T_{\text {mPAB }}$ is interpreted as indicating not only that the tubule cells had lost their ability to excrete $\mathrm{PAH}$ but that a portion of the $\mathrm{PAH}$ filtered by the glomeruli was escaping from the tubular urine by back-diffusion. It is the purpose of this paper to describe quantitatively the pattern of glomerular and tubular functional changes following the period of anuria to apparent functional recovery.

On March 1, 1945 an 8-year-old white female developed sore throat and fever. There was no history of previous renal disease. She received approximately 3.0 grams of sulfathiazole in the form of chewing gum from March 3 to March 6. On March 6, vomiting occurred and continued for 10 days; March 7, anuria appeared and persisted for 4 days, followed by marked oliguria for $\mathbf{5}$ days. On the third day of anuria, a discrete, macular, erythematous rash appeared on all 4 extremities, and extended during the next 2 days to involve the face and become confluent on the upper extremities. On the fourth day of anuria, bilateral conjunctivitis appeared. The rash and conjunctivitis were present for 10 days. Systolic blood pressure ranged from 130 to $120 \mathrm{~mm}$. and the diastolic from 96 to $80 \mathrm{~mm}$. $\mathrm{Hg}$ from the fifth to the ninth day following onset of anuria. Three weeks later, the blood pressure was $11 \%$ mm. Blood non-protein nitrogen was $214 \mathrm{mgm}$. per cent 5 days following the onset of anuria and fell gradually to $21 \mathrm{mgm}$. per cent over a period of 3 weeks. Carbon dioxide combining power was 48 and 57 volumes per cent on the sixth and eighth days following the onset of anuria. Plasma chlorides rose from 71 milliequivalents to 104 in 3 weeks. The red blood cell count, hemoglobin and plasma proteins were normal. Four days following onset of anuria, the patient voided 15 ml. of urine in which a trace of protein was present, red and white cells were absent, and sulfathiazole crystals were seen; the plasma level of sulfathiazole at this time was $2 \mathrm{mgm}$. per cent. On the seventh and eighth days following onset of anuria, the urine contained moderate amounts of protein, 20 to 50 red blood cells per high power field, and innumerable white blood cells. In 3 weeks, the urine contained no protein or cellular elements.
Spontaneous diuresis occurred on the tenth day following the onset of anuria and apparently was not related to any specific therapeutic measure.

The patient was discharged from the hospital 39 days after the onset of anuria, and has been observed for a period of 92.5 weeks following the onset of anuria at the Nephritis and Hypertension Clinic, New York University Clinic. She has attended the clinic at regular intervals and has been symptom free; edema has been absent and the blood pressure has varied from $110 / 74$ to $92 / 68 \mathrm{~mm}$. $\mathrm{Hg}$; proteinuria reappeared and has persisted, varying from a trace to 2 plus. Hematuria and pyuria have been absent.

\section{METHODS}

The rate of glomerular filtration, the effective renal plasma flow, and the maximal tubular excretory capacity $\left(T_{\text {mPAB }}\right)$ were measured according to the technique described by Goldring and Chasis (1).1 Intravenous infusion for maintaining plasma levels and bladder catheterization to insure complete bladder emptying were employed.

\section{RESULTS}

The results of 5 determinations of specific renal functions are presented in Table I. Two weeks after the onset of anuria, the mannitol and p-aminohippurate clearances were markedly below the

TABLE I

\begin{tabular}{|c|c|c|c|c|c|}
\hline \multirow{2}{*}{$\begin{array}{c}\text { Time } \\
\text { from } \\
\text { onset of } \\
\text { anuria }\end{array}$} & \multicolumn{2}{|c|}{ Plasma clearance* } & \multirow{2}{*}{$T_{\mathrm{mPAH}}$} & \multirow{2}{*}{$\begin{array}{l}\text { Filtration } \\
\text { fraction } \\
\left(C_{m} / C_{P A H}\right)\end{array}$} & \multirow{2}{*}{ Proteinuria } \\
\hline & $\begin{array}{c}\text { Manni- } \\
\text { tol } \\
\left(\mathrm{C}_{m}\right)\end{array}$ & $\underset{\text { (CPAH) }}{\text { PAH }}$ & & & \\
\hline weeks & \multicolumn{2}{|c|}{ ml. per minute } & $\underset{\text { per min. }}{\operatorname{mgm} .}$. & per cent & \\
\hline $\begin{array}{r}2.0 \\
3.5 \\
4.5 \\
7.0 \\
92.5\end{array}$ & $\begin{array}{r}17.2 \\
75.0 \\
79.6 \\
108.4 \\
91.0\end{array}$ & $\begin{array}{r}14.6 \\
220.4 \\
443.0 \\
448.5 \\
586.0\end{array}$ & $\begin{array}{r}-1.1 \\
-9.4 \\
20.3 \\
42.7 \\
85.6\end{array}$ & $\begin{array}{l}34.0 \\
17.7 \\
24.2 \\
15.6\end{array}$ & $\begin{array}{l}\text { Trace } \\
\text { None } \\
\text { None } \\
\text { Trace } \\
\text { Two plus }\end{array}$ \\
\hline
\end{tabular}

* All clearance values corrected to 1.73 square meters surface area.

1 Clearances corrected as suggested by Barker and Clark (2). 
mean normal values for females (117 and $594 \mathrm{ml}$. per minute, respectively) and $\mathrm{T}_{\mathrm{mPAB}}$ had a negative value of $-1.1 \mathrm{mgm}$. per minute as compared to the normal value of $82.2 \mathrm{mgm}$. per minute (3). This observation was made 1 week after spontaneous diuresis had occurred and while the blood urea was $93 \mathrm{mgm}$. per cent.

Three and one-half weeks after the onset of anuria, the mannitol and $\mathrm{p}$-aminohippurate clearances had increased significantly, while $\mathrm{T}_{\mathbf{m P A B}}$ continued to have a negative value.

Four and one-half weeks and 7 weeks after the onset of anuria, the mannitol clearance had returned to the normal range, the p-aminohippurate clearance was aproaching normal, and $T_{\mathrm{mAB}}$ had increased to significant positive values. The blood urea at this time was normal and the urine contained no protein or abnormal cellular elements.

Ninety-two and one-half weeks after the onset of anuria, the above renal functions were in the normal range. The urine contained a moderate amount of protein.

\section{DISCUSSION}

Skin rash, conjunctivitis, anuria, sulfonamide crystalluria, and sulfonamide in the plasma 5 days after the onset of anuria are interpreted as manifestations of sulfonamide intoxication. Proteinuria persisting for a period of nearly 2 years can be attributed either to sulfonamide intoxication or to some other concurrent process, e.g. diffuse glomerulonephritis. The possibility that acute diffuse glomerulonephritis was superimposed cannot be excluded; but it does not change the significance of the pattern of acute renal functional impairment, which we believe is related to the prolonged period of anuria, rather than to a specific noxious agent. The total dosage of sulfathiazole is relatively small, but it is known that sulfonamide intoxication does not bear a uniform quantitative relationship to the amount of drug administered. Death from renal insufficiency has been reported in a 1-year-old child following the administration of 0.65 gram of sulfathiazole (4).

Smith has emphasized the limitations of the clearance methods in the diseased kidney (5). The use of mannitol as a measure of glomerular filtration is based on the assumption that none of the filtered mannitol is reabsorbed by the tubules.
The markedly decreased mannitol clearance first observed following anuria cannot be taken as an accurate measurement of glomerular filtration, since the reduction may have been caused in part by tubular back-diffusion. However, we believe that the mannitol clearance is a reliable index of glomerular filtration $4 \frac{1}{2}$ weeks after the onset of anuria, since back-diffusion had apparently disappeared, as indicated by the positive value for $T_{\text {mPAB }}$ and the normal value for the blood non-protein nitrogen. Had tubular damage been extensive enough to permit back-diffusion of mannitol at this time, it is logical to assume that the more diffusible urea would also have diffused back, causing an elevation of the blood non-protein nitrogen. The anuria and azotemia during the acute episode may be attributed in part to glomerular and in part to tubular damage.

It is probable that the $\mathrm{PAH}$ extraction ratio was reduced in the first 2 series of observations. A decrease in this extraction ratio has been reported after extreme reduction of renal blood flow in the $\operatorname{dog}(4,6$ to 8$)$. Hence, until the last observation, the PAH clearance cannot be taken as accurately indicating the renal blood flow. Although the normal value of the filtration fraction at $4 \frac{1}{2}$ weeks implies a normal extraction -ratio at this time, tubular impairment was still present at 7 weeks, as manifested by the reduced value of $T_{\text {mpAB }}$.

The negative $T_{\text {mPAB }}$ value after anuria indicates that $\mathrm{PAH}$ was diffusing back through the tubules at some point. $^{2}$ It may be suggested as a mere speculation that the tubular segment most susceptible to anoxic injury is the thin limb of the loop of Henle; on the supposition that PAH is excreted by the proximal tubule, a negative value of $T_{\text {mPA }}$ does therefore not necessarily imply that this process of excretion was specifically impaired, though some impairment is certainly to be anticipated after a prolonged period of glomerular damage or vascular spasm. Such marked functional disorganization is probably indicative of wide-

2 The maximal urine mannitol blanks observed in patients in uremia have been approximately $3.76 \mathrm{mgm}$. per minute (9). Such a correction applied to those determinations in this patient in which negative $T_{m}$ values were observed would not result in positive values for $T_{m}$. However, in view of the low mannitol clearance, it seems probable that some back-diffusion of both mannitol and PAH occurs. 
spread changes involving glomeruli, tubules, and interstitium, such as have been described at necropsy in patients with fatal sulfonamide intoxication (4). Luetscher and Blackman (10) reported an unusual increase in the concentration of serum sodium and chloride in patients with sulfathiazole intoxication at a time when oliguria and nitrogen retention were diminishing, and they correlated this finding with the renal lesions observed in the tubules at necropsy. At $3 \frac{1}{2}$ weeks, despite the fact that glomerular function had apparently returned to the normal range, the persistent negative value for $T_{\text {MPAB }}$ indicates that the tubular cells were still so disorganized as to permit abnormal backdiffusion. It was not until $4 \frac{1}{2}$ weeks after the onset of anuria that a positive value for $T_{\text {mPAB }}$ was obtained. The eventual return of $T_{\text {mPAB }}$ to normal indicates that the tubular injury in this patient did not result in permanent loss of excretory capacity. Bradley (11) and Rubin (7) have observed negative values for $T_{\text {mPAB }}$ in patients with diffuse glomerulonephritis.

The primary disturbance producing immediate and subsequent renal injury during anuria, whether the anuria is associated with diffuse glomerulonephritis, post-transfusion reaction, sulfathiazole intoxication, crush syndrome, battle casualties with peripheral circulatory failure, or ureteral trauma, may be renal ischemia. Theoretically, the course of events in this patient may have started with marked renal ischemia initiated reflexly from the ureter or from intrarenal pathology.

\section{SUMMARY}

Marked reduction in renal function was observed early in the postanuric stage in a patient with sulfathiazole intoxication.
The filtration rate returned fairly rapidly to normal. Tubular excretory capacity, however, was impaired for a longer period of time, but eventually returned to normal.

A negative value for $T_{\text {mPAB }}$ indicating abnormal tubular back-diffusion of $\mathrm{PAH}$ persisted for approximately 4 weeks from the onset of anuria.

\section{BIBLIOGRAPHY}

1. Goldring, W., and Chasis, H., Hypertension and $\mathrm{Hy}-$ pertensive Disease, Commonwealth Fund, New York, 1944, p. 212.

2. Barker, H. G., and Clark, J. K., Effect of p-aminohippurate on mannitol determinations by the periodate-iodide-thiosulfate method. Proc. Soc. Exper. Biol. and Med., 1947, 64, 120.

3. Chasis, H., Redish, J., Goldring, W., Ranges, H. A., and Smith, H. W., The use of sodium p-aminohippurate for the functional evaluation of the human kidney. J. Clin. Invest., 1945, 24, 583.

4. Murphy, F. D., Kuzma, J. F., Polley, T. Z., and Grill, J., Clinicopathologic studies of renal damage due to sulfonamide compounds. Arch. Int. Med., 1944, 73, 433.

5. Smith, Homer W., Note on the interpretation of clearance methods in the diseased kidney. J. Clin. Invest., 1941, 20, 631.

6. Corcoran, A. C., and Page, I. H., Effects of hypotension due to hemorrhage and of blood transfusion on renal function in dogs. J. Exper. Med., 1943, 78, 205.

7. Rubin, Mitchell I., Personal communication.

8. Selkurt, E. E., The changes in renal clearance following complete ischemia of the kidney. Am. J. Physiol., 1945, 144, 395.

9. Earle, David, Personal communication.

10. Luetscher, J. A., Jr., and Blackman, S. S., Jr., Severe injury to kidneys and brain following sulfathiazole administration; high serum sodium and chlorides levels and persistent cerebral damage. Ann. Int. Med., 1943, 18, 741.

11. Bradley, Stanley, Personal communication. 